\title{
RATING OF AGRICULTURAL PRODUCERS IN THE CENTRAL ZONE OF KRASNODAR TERRITORY
}

Key words: rating; agriculture; analysis; crop acreage; financial activity; production; integral assessment; linear transformation; additive method.

\section{Authors' personal details}

1. Veronika Molodchenko, 2nd-year student of the Faculty of Applied Informatics, Kuban State Agrarian University, named after I.T. Trubilin, 350044, Krasnodar, Kalinin St., 13, e-mail: veron_mol@mail.ru.

2. Sergey Kosnikov, Candidate of Economic Sciences, Associate Professor, Kuban State Agrarian University named after I.T. Trubilin, 350044, Krasnodar, Kalinina St., 13.

Currently, agriculture's status and development as one of the largest sectors of the agro-industrial complex is a relevant issue. The paper reviews the research and monitoring data on various characteristics of the industry among the subjects of the central zone of Krasnodar territory. The paper highlights the main areas and functions of agriculture. Information on the activities within municipalities is publicly available. It is posted on the website of the Federal state statistics service. The paper shows options in the municipalities' activities for economic efficiency, sustainable production, and potential use of rural areas. The paper describes suitable methods, identifies evaluation stages, provides a rationale of parameters and indices. They are reduced to comparable terms by standardization, convolution, rating search. The process involves calculating integral indices by additive convolution, differentiation of mu-

(C) Молодченко В.Ю., Косников С.Н. nicipalities, and their ranking. As a result, index and parameter values are derived. Based on the values, the activity problems can be revealed, and solutions to the problems can be elaborated. The ranking system helps manage and stimulate the region's central zone's object to achieve a particular position. The research has determined the level of agricultural development in the region and identified the system's specific elements. Based on the research findings, an implementation plan can be created for achieving high results in various categories. Thus, the integral assessment provides the basis for creating a ranked list. The procedures clarify the structure of agriculture, determine the advantages in working and managing the sector, detect and allow for the elimination of shortcomings, and determine measures to improve the existing conditions.

УДК 637.1

DOI: $10.31563 / 1684-7628-2020-55-3-31-38$

В.А. Асафов, В.Д. Харитонов, Н.Л. Танькова, Е.Л. Искакова, П.В. Кузнецов, В.Т. Габриелова

\section{НЕКОТОРЫЕ АСПЕКТЫ ИСПОЛЬЗОВАНИЯ РАЗЛИЧНЫХ ИСТОЧНИКОВ СОЕВОГО БЕЛКА В РАЦИОНАХ КОРМЛЕНИЯ ТЕЛЯТ}

\footnotetext{
Ключевые слова: заменитель цельного молока; изолят соевого белка; гидролиз белков; соевая мука; факторы кормления; рост телят.
}

Введение. От правильного развития молодняка в определенной степени зависит реализация генетического потенциала молочной продуктивности дойного стада, включая продолжительность лактации, а также экономические аспекты производства молока. Для этого теленку необходимо скармливать не менее 300-350 литров молока. Для поддержания товарного произ- водства молока требуется ежегодное пополнение молодняка в молочном стаде - около 40 голов на 100 коров [1]. Поголовье коров в России составляет в настоящее время около 8,0 млн голов, а за вычетом поголовья личных подсобных хозяйств - 4,6 млн голов [2]. Для этого поголовья молодняка требуется около 1,3 млн т молока. $\mathrm{B}$ то же время использование цельного молока 
для выпойки телят снижает товарность молока и увеличивает затраты на содержание стада.

Для повышения товарности и сокращения издержек при выращивании животных используют различные виды заменителей цельного молока (ЗЦМ). Оценочная потребность в ЗЦМ составляет 100-120 тыс. т в пересчете на сухие вещества. В настоящее время известны и используются следующие основные типы ЗЦМ [3]: на обезжиренном молоке и немолочных жирах; на концентрате белков молочной сыворотки и немолочных жирах; на молочной сыворотке, концентратах и изолятах соевого белка и немолочных жирах; на молочной сыворотке, соевой муке и немолочных жирах.

По способу производства различают: продукт, приготовленный в жидком виде и высушенный на распылительной сушилке; регенерированное молоко - продукт, приготовленный сухим смешиванием ингредиентов, включая жир.

Каждый из способов имеет свои преимущества и недостатки. Более технологично в изготовлении регенерированное молоко. Однако в этом случае имеется проблема внесения жиров. Корм для телят не должен содержать свободных жиров. При их наличии телята плохо усваивают корм и плохо развиваются. Поэтому, как правило, регенерированное молоко имеет невысокий процент жира (12\%). При этом соотношение жир/белок составляет $0,5 / 1$, тогда как в молоке - 1,2/1. Таким образом, телята могут недополучать необходимую для роста энергию или потреблять больше корма для ее восполнения. Производство ЗЦМ в России составляет 10-11 тыс. т, а по импорту поступает около 32 тыс. т [4]. Современное состояние производства ЗЦМ не обеспечивает потребностей животноводства в нем.

С нашей точки зрения, для развития рынка ЗЦМ необходима разработка новых конкурентных методов их получения на основе процессов ферментации и консервирования с различной степенью обезвоживания с целью улучшения качества и снижения сырьевой себестоимости [5, 6]. Перспективным направлением в этой связи является ферментативная обработка растительного сырья и использование многостадийного обезвоживания, в том числе на основе получения продуктов с промежуточной влажностью [6]. Современное производство ЗЦМ базируется в основном на использовании молочной сыворотки, немолочных жиров и белков. Наиболее проблемным компонентом в рецептурах ЗЦМ является источник растительного белка. Как правило, с этой целью применяют различные виды источников белков: соевую муку, концен- траты и изоляты белков сои. Соевая мука содержит ряд антипитательных веществ, включая лектины, олигосахара и аллергены. Эти компоненты не равноценны по качеству и в ряде случаев требуют специальной обработки для использования в ЗЦМ. К изолятам и концентратам белков сои также применяют специальные требования, в основном в части контроля антигенов [7].

Таким образом, развитие исследований и теоретических обобщений в области новых видов конкурентоспособных кормов для молодняка сельскохозяйственных животных является актуальным, в том числе происходящее путем осуществления выбора и реализации оптимальных для данной технологии способов обезвоживания, ресурсо- и энергосбережения, а также получения продуктов повышенного качества.

Целью исследований, проводимых ФГАНУ «ВНИМИ», является разработка энерго- и ресурсосберегающих технологий ферментированных видов заменителей цельного молока для молодняка с.-х. животных с различной степенью обезвоживания [6]. В данной работе приводятся результаты зоотехнической оценки ЗЦМ на основе различных источников белков.

Одним из перспективных направлений повышения качества ЗЦМ является использование специализированных видов соевого белка, обладающих оптимизированным составом компонентов или подвергнутых определенной биотехнологической трансформации с целью расширения спектра функциональных свойств [7]. В частности, потенциально определенных преимуществ в данной области можно достичь, используя гидролиз белковых компонентов в ЗЦМ. Это связано с тем, что гидролизованные белки позволяют осуществлять изменение его пептидного профиля и на этой основе модификацию свойств в нужном направлении [8, 9]. Кроме того, существенным фактором, определяющим качество белков, предназначенных для кормления молодняка, являются их антигенные свойства, регулирование которых можно осуществлять путем ферментативной обработки [10].

Некоторые аспекты, связанные с вырашиванием телят. Важным аспектом, который необходимо учитывать, является решение вопросов оптимизации состава и использования ЗЦМ в структуре питания молодняка сельскохозяйственных животных. На выращивание молодняка приходится 20 \% общих затрат, связанных с производством молока. Наиболее эффективным способом снижения этих затрат является сокращение времени выращивания. Естественно, что достижение соответствующей ско- 
рости роста зависит от успешного выращивания молодняка. Это позволяет ему набрать нормальную массу и обеспечить первый отел в идеальном возрасте. Оптимальный возраст первого отела - около 24 месяцев. Если отел приходится на возраст в 2,5 и более лет, то это значит, что необходимо содержать больше скота [1].

Другим фактором, который учитывается при выращивании молодняка, является масса животного при первом отеле. Исследования по определению оптимальной массы телок фризской и голштинской пород в различной возрастной категории показали, что для достижения массы 110 кг и 130 кг в первые 4 месяца жизни телята этих пород должны набирать в среднем ежедневно по 0,6 и 0,7 кг соответственно (таблица 1) $[11]$.

Скорость роста телок влияет также на возраст половой зрелости и, соответственно, на массу при первом отеле. Если телята растут очень медленно (<0,35 кг/день), то половая зре- лость не наступает до 18-20 месяцев [12]. Слишком интенсивная скорость роста телок может быть так же вредной, как и слишком медленная. Установлено, в частности, что интенсивный или «ускоренный» рост, который ведет к ожирению до половой зрелости, снижает процесс развития ткани молочной железы. Критический период развития ткани молочной железы - от трех до десяти месяцев. Имеются данные о том, что ускоренный рост в этот период в дальнейшем снижает выход молока. Коровы при избыточном росте до наступления половой зрелости не дают столько молока во время первой или последующей лактации, как коровы, рост которых находился под контролем (таблица 2) [13].

Таким образом, несмотря на то, что есть много факторов, которые могут повлиять на здоровье, рост телок и их продуктивность, организация правильной программы кормления и важность кормления молоком или ЗЦМ вместе со стартером очевидны [1].

Таблица 1 Рекомендуемая масса молодняка, кг

\begin{tabular}{|c|c|c|}
\hline \multirow{2}{*}{ Возраст животного (мес.) } & \multicolumn{2}{|c|}{ Стандартная масса для породы } \\
\cline { 2 - 3 } & фризская & голштинская \\
\hline 0 & 40 & 45 \\
\hline 4 & 110 & 275 \\
\hline 10 & 220 & 325 \\
\hline 12 & 250 & 400 \\
\hline 15 & 320 & 575 \\
\hline 22 & 480 & 600 \\
\hline
\end{tabular}

Таблица 2 Влияние скорости роста молодняка Голштинской породы до наступления половой зрелости на выработку молока при первой лактации

\begin{tabular}{|l|c|c|}
\hline \multicolumn{1}{|c|}{ Показатель } & $\begin{array}{c}\text { Контролируемая } \\
\text { скорость роста }\end{array}$ & $\begin{array}{c}\text { Интенсивная } \\
\text { скорость роста }\end{array}$ \\
\hline Скорость роста до наступления половой зрелости, кг/день & 0,7 & 1,01 \\
\hline Масса тела (перед отелом), кг & 623 & 613 \\
\hline Выход молока за 305 дней лактации, кг & 8305 & 7800 \\
\hline
\end{tabular}

Материалы, методы и результаты исследований. ФГАНУ «ВНИМИ» совместно с компанией «Дюпон» проводились исследования по изучению скорости роста молочных телят, вскармливаемых заменителями молока с соевым белком из различных источников.

Цель эксперимента - проведение зоотехнической оценки эффективности использования заменителей цельного молока на основе гидролизованного соевого белка при выкармливании телят в возрасте от 4 до 84 дней.

Эксперимент проводился путем набора опытных групп телят, которых выкармливали согласно схемам кормления, представленным в таблицах 3,4 и 5.
В эксперименте использовались:

1. Заменитель цельного молока на основе гидролизованного изолята соевого белка с массовой долей жира $16 \%$ согласно рецептуре, разработанной ВНИМИ.

2. Промышленный заменитель цельного молока на основе обезжиренного молока с массовой долей жира $16 \%$.

3. Промышленный заменитель цельного молока на основе соевой муки с массовой долей жира $16 \%$.

Каждую группу телок в количестве 12 голов отбирали в первый день жизни, при этом исключали заведомо больных телят. Группы рандомизировали по полу, общему состоянию и средней массе телят. 
Таблица 3 Схема кормления телят до 3-месячного возраста с применением ЗЦМ на основе гидролизованного соевого белка

\begin{tabular}{|c|c|c|c|c|}
\hline \multirow{2}{*}{$\begin{array}{c}\text { Возраст телят, } \\
\text { недели / дни }\end{array}$} & \multirow{2}{*}{$\begin{array}{c}\text { Ежедневное потребление } \\
\text { молозива / ЗЦМ }\end{array}$} & \multirow{2}{*}{\begin{tabular}{|c|} 
Количество \\
ЗЦМ (г) / воды (л) \\
на одно кормление
\end{tabular}} & \multicolumn{2}{|c|}{ Потребление грубых кормов } \\
\hline & & & комбикорм / стартер & сено, силос \\
\hline 1-2 день & Молозиво 1,5 л × $\mathbf{4}$ p/день & $x_{1}=1$ & \multirow{6}{*}{-} & \multirow{6}{*}{-} \\
\hline 3 день & Молозиво 1,5 л × $\mathbf{3}$ р/день & - & & \\
\hline 4 день & Молоко $3 / 4+$ ЗЦМ 1/4 1,5 л × 3 p/день & $47 / 0,33$ & & \\
\hline 5 день & Молоко $1 / 2+3 Ц М ~ 1 / 21,5$ л $\times \mathbf{3}$ p/день & $94 / 0,66$ & & \\
\hline 6 день & Молоко $1 / 4+$ ЗЦМ 3/4 1,5 л × $\mathbf{3}$ р/день & $141 / 0,98$ & & \\
\hline 7-10 день & \multirow{2}{*}{ ЗЦМ 2 л × 2 р/день } & \multirow{2}{*}{$250 / 1,75$} & & \\
\hline 11-14 день & & & Приучение ( 50 г/день) & \multirow{8}{*}{$\begin{array}{c}\text { Сено и силос } \\
\text { без ограничений, } \\
\text { вода по необходи- } \\
\text { мости }\end{array}$} \\
\hline 3 нед. & ЗЦМ 3,2 л × $\mathbf{2}$ р/день & $400 / 2,8$ & До 300 г/день & \\
\hline 4 нед. & ЗЦМ 4 л × 2 р/день & $500 / 3,5$ & До 500 г/день & \\
\hline 5 нед. & ЗЦМ 4 л $\times \mathbf{2}$ р/день & $500 / 3,5$ & До 800 г/день & \\
\hline 6 нед. & ЗЦМ 4 л × 2 p/день & $500 / 3,5$ & До 1200 г/день & \\
\hline 7 нед. & ЗЦМ 3,6 л × 2 р/день & $450 / 3,15$ & До 1400 г/день & \\
\hline 8 нед. & ЗЦМ 3,6 л × 1 p /день & $450 / 3,15$ & До 1700 г/день & \\
\hline 9 нед. & ЗЦМ 2,4 л × 1 p/день & $300 / 2,10$ & \multirow{2}{*}{$\begin{array}{c}\text { Стандартный комбикорм } \\
\text { по потребности } \\
\text { (2-3 кг/день })\end{array}$} & \\
\hline 10-12 нед. & ЗЦМ 1,5 л × 1 p/день по необходимости & $188 / 1,3$ & & Неограниченно \\
\hline
\end{tabular}

Таблица 4 Схема кормления телят до 3-месячного возраста с применением ЗЦМ с обезжиренной соевой мукой

\begin{tabular}{|c|c|c|c|c|}
\hline \multirow{2}{*}{$\begin{array}{c}\text { Возраст телят, } \\
\text { недели / дни }\end{array}$} & \multirow[b]{2}{*}{ Ежедневное потребление молозива / ЗЦМ } & \multirow{2}{*}{$\begin{array}{c}\text { Количество } \\
\text { ЗЦМ (гр) / воды (л) } \\
\text { на кормление }\end{array}$} & \multicolumn{2}{|c|}{ Потребление грубых кормов } \\
\hline & & & $\begin{array}{c}\text { комбикорм } \\
\text { «Стартер» }\end{array}$ & сено (г/день) \\
\hline 1 день & Молозиво 1 л × 4 p/день & - & \multirow{3}{*}{$x_{10}$} & \multirow{3}{*}{-} \\
\hline 2-4 день & Молозиво 1 л $\times 3$ p/день & - & & \\
\hline 5-7 день & Молозиво 1 л $\times 1$ p/день, ЗЦМ 1 л × 2 p/день & $100 / 0,9$ & & \\
\hline 2 нед. & ЗЦМ 2 л $\times 2$ p/день & $200 / 1,8$ & С 10-ого дня 50 гр & 50 \\
\hline 3 нед. & ЗЦМ 2 л $\times 2$ р/день & $200 / 1,8$ & 100 & 50 \\
\hline 4 нед. & ЗЦМ 2 л $\times 2$ p/день & $200 / 1,8$ & 150 & 50 \\
\hline 5 нед. & ЗЦМ 3 л × 2 p/день & $300 / 2,7$ & 250 & 100 \\
\hline 6 нед. & ЗЦМ 3 л × 2 p/день & $300 / 2,7$ & 400 & 150 \\
\hline 7 нед. & \multirow{2}{*}{ ЗЦМ 2 л × 2 p/день } & \multirow{2}{*}{$200 / 1,8$} & 600 & 200 \\
\hline 8 нед. & & & 800 & 300 \\
\hline 9 нед. & \multirow{2}{*}{ ЗЦМ 2 л × 2 p/день } & \multirow{2}{*}{$200 / 1,8$} & 1000 & 400 \\
\hline 10 нед. & & & 1500 & 500 \\
\hline
\end{tabular}

Таблица 5 Схема кормления телят до 3-месячного возраста с применением ЗЦМ на основе обезжиренного молока

\begin{tabular}{|c|c|c|c|c|}
\hline \multirow[b]{2}{*}{$\begin{array}{c}\text { Возраст телят, } \\
\text { недели / дни }\end{array}$} & \multirow[b]{2}{*}{ Ежедневное потребление молозива/ ЗЦМ } & \multirow{2}{*}{$\begin{array}{c}\text { Количество } \\
\text { ЗЦМ (гр.) / воды (л) } \\
\text { на кормление }\end{array}$} & \multicolumn{2}{|c|}{ Потребление грубых кормов } \\
\hline & & & $\begin{array}{c}\text { комбикорм } \\
\text { «Стартер» } \\
\end{array}$ & $\begin{array}{c}\text { сена, силоса, } \\
\text { воды }\end{array}$ \\
\hline 1-2 день & Молозиво 1,5 л × 4 раза в день & - & \multirow{3}{*}{-} & \multirow{3}{*}{-} \\
\hline 3 день & Молозиво 1,5 л $\times 1$ p/день, ЗЦМ 1 л × 2 p/день & $125 / 0,875$ & & \\
\hline 4-7 день & ЗЦМ 1,5 л $\times 2$ p/день & $187 / 1,3$ & & \\
\hline 8-14 день & ЗЦМ 2 л × 2 р/день & $250 / 1,75$ & С 10-ого дня 50 г/день & \multirow{9}{*}{$\begin{array}{c}\text { вода } \sim 10 \% \\
\text { массы те- } \\
\text { ленка в одно } \\
\text { кормление, } \\
\text { сено и силос } \\
\text { без ограниче- } \\
\text { ний }\end{array}$} \\
\hline 3 нед. & ЗЦМ 2,5 л × 2 p/день & $312 / 2,2$ & 100 г/день & \\
\hline 4 нед. & ЗЦМ 3 л × 2 р/день & $375 / 2,6$ & 250 г/лень & \\
\hline 5 нед. & ЗЦМ 3,5 л × 2 p/день & $437 / 3,1$ & 250 17день & \\
\hline 6 нед. & ЗЦМ 3 л × 2 р/день & $375 / 2,6$ & 400 г/день & \\
\hline 7 нед. & \multirow{2}{*}{ ЗЦМ 2,5 л × 2 p/день } & \multirow{2}{*}{$312 / 2,2$} & 600 г/день & \\
\hline 8 нед. & & & 800 г/день & \\
\hline 9 нед. & \multirow{2}{*}{ ЗЦМ 2 л × 2 p/день } & \multirow{2}{*}{$250 / 1,75$} & 1000 г/день & \\
\hline 10 нед. & & & 1500 г/день & \\
\hline 11 нед. & \multirow{2}{*}{ ЗЦМ 1,5 л × 2 р/день } & \multirow{2}{*}{$187 / 1,3$} & 1800 г/день & \multirow{2}{*}{$\begin{array}{c}\text { без ограниче- } \\
\text { ний } \\
\end{array}$} \\
\hline 12 нед. & & & 2000 г/день & \\
\hline
\end{tabular}


Помимо заменителей цельного молока в эксперименте всем группам телят давали с 10-ти дней вволю воду, сено хорошего качества (и/или подвяленную траву, сухой силос) и комбикорм следующего состава:

$\begin{array}{lr}\text { Просо } & 25,0 \% \\ \text { Пшеница } & 22,6 \% \\ \text { Овес } & 15,0 \% \\ \text { Кукуруза } & 15,0 \% \\ \text { Соевый шрот } & 14,0 \% \\ \text { Подсолнечниковый шрот } & 5,0 \%\end{array}$

Известняк

Трикальцийфосфат

Метаболическая энергия (Мкал/кг с. в.) 2,9

Комбикорм нормировали из расчета 60 кг на теленка до 84 дня жизни. В процессе проведения эксперимента ежедневно регистрировалось общее состояние здоровья, аппетит, ветеринарные процедуры (если производились) для каждого теленка; ежедекадно регистрировались масса и количество съеденных грубых кормов (таблица 6).

Таблица 6 Средняя живая масса молодняка

\begin{tabular}{|l|c|c|c|c|c|c|}
\hline \multicolumn{1}{|c|}{ Вид ЗЦМ } & \multicolumn{5}{c|}{ День жизни теленка } \\
\cline { 2 - 6 } & 5 & 30 & 60 & 85 & 120 & 150 \\
\hline 1. ЗЦМ на основе гидролизованного соевого белка. Масса теленка, кг & 44,7 & 53,5 & 71,2 & 91,9 & 123,6 & 151,2 \\
\hline Среднесуточный прирост за месяц, г & - & 293 & 590 & 690 & 1057 & 920 \\
\hline Доверительный интервал & 2,4 & 2,7 & 3,1 & 4,3 & 8,1 & 7,5 \\
\hline 2. ЗЦМ на основе сухого обезжиренного молока. Вес теленка, кг & 43,9 & 48,4 & 63,6 & 80,0 & 113,4 & 136,1 \\
\hline Среднесуточный прирост за месяц, г & - & 150 & 507 & 547 & 1113 & 757 \\
\hline Доверительный интервал & 2,6 & 1,9 & 2,9 & 5,7 & 9,9 & 10,4 \\
\hline 3. ЗЦМ на основе обезжиренной соевой муки. Масса теленка, кг & 43,5 & 41,7 & 56,3 & 76,8 & 107,1 & 110,1 \\
\hline Среднесуточный прирост за месяц, г & - & -60 & 486 & 683 & 1010 & 100 \\
\hline Доверительный интервал & 2,9 & 2,7 & 6,4 & 7,7 & 7,6 & 8,7 \\
\hline
\end{tabular}

Проведена также оценка общего состояния, состояния здоровья в группах:

1. Группа, получавшая ЗЦМ на основе гидролизованного соевого белка: общее состояние телят в группе хорошее, отклонений от физиологической нормы для данного возраста не обнаружено, состояние здоровья хорошее, из группы был выбракован один теленок в возрасте 2,5 месяца с диагнозом бронхопневмония.

2. Группа, получавшая ЗЦМ на основе обезжиренного молока: общее состояние телят в группе хорошее, отклонений от физиологической нормы для данного возраста не обнаружено, состояние здоровья хорошее.

3. Группа, получавшая ЗЦМ на основе соевой муки: общее состояние телят в группе неудовлетворительное, телята отстают в росте, часто болеют. В группе пал один теленок в возрасте 1 месяца - диагноз бронхопневмония, осложненная гастроэнтеритом; три теленка выбракованы в возрасте 1,5 месяцев с диагнозом бронхопневмония и авитаминоз. Результаты, представленные в таблице 6, показывают дан- ные о росте телят в виде среднесуточного прироста и живой массы через 150 дней.

Показатели роста телят, вскармливаемых заменителями молока на основе гидролизованного соевого белка, были выше, чем при вскармливании другими кормами. Среднесуточный прирост 740 г/день можно считать удовлетворительным для телок в фазе развития до достижения половой зрелости. Заданная масса через 150 дней достигалась при использовании заменителя молока на основе гидролизованного изолята соевого белка. За тот же период рост телят, вскармливаемых заменителем молока, содержащим соевую муку, был очень медленным и недостаточным для достижения заданной массы.

Заключение. При использовании заменителей цельного молока для выпойки телят особое внимание следует обращать на выбор источника белка, который используется в рецептурах. Удовлетворительного роста телят молочных пород можно достичь при употреблении ЗЦМ на основе очищенных и гидролизованных соевых белков.

\section{Библиографический список}

1. Kertz A.F., Hill T.M., Quigley J.D., Heinrichs A.J., Linn J.G., Drackley J.K. A 100-Year Review: Calf nutrition and management. J. Dairy Sci. 100:10151-10172. https://doi.org/10.3168/jds.201713062 .
2. Демидова, М. Эксперты сельхозпереписи посчитали, сколько в России коров [Электронный ресурс] // М. Демидова. Режим доступа: https://yakapitalist.ru/finansy/skolko-v-ros sii-korov. Москва, 1 июня 2019 года. 
3. Радаева, И.А. Технология молочных консервов и заменителей цельного молока [Текст]: справочник / И.А. Радаева, В.С. Гордезиани, С.П. Шулькина. М.: Агропромиздат, 1986. $351 \mathrm{c}$.

4. Обзор рынка: заменители цельного молока [Текст] / Г. Локтионова // Ценовик. 2013. № 3.

5. Асафов, В.А. Концентрированные формы заменителя молока на растительной основе для молодняка сельскохозяйственных животных [Текст]/ В.А. Асафов, Ю.И. Филатов, Н.Л. Танькова, Е.Л. Искакова, В.В. Мяленко // Научное обеспечение молочной промышленности (ВНИМИ80): сборник научных трудов. М., 2009. С. 18-20.

6. Kharitonov V.D., Burlev M.Ya., Kuznetsov P.V., Mertinc P. Some Reculiazities related to formation of Dried Milk Products properties. J. Food and Raw Materials. 2017. T. 5. № 2. P. 161-167.

7. Зобкова, 3.С. Продукты на основе соевых компонентов для профилактического и диетического питания [Текст] / 3.С. Зобкова, Т.П. Фурсова // Молочная промышленность. 1998. № 5. С. 15-16.

8. Зорин, С.Н. Ферментативные гидролизаты пищевых белков для специализированных пищевых продуктов диетического (лечебного и профилактического) питания [Текст] // Вопросы питания. 2019. Т. 88, № 3. С. 23-31. doi: 10.244 11/0042-8833-2019-10026.

9. Агаркова, Е.Ю. Ферментативная конверсия как способ получения биологически активных пептидов [Текст] / Е.Ю. Агаркова, А.Г. Кручинин // Вестник МГТУ. 2018. Т. 21. № 3 (июльсентябрь). С. 412-417.

10. Long He, Meng Han, Shiyan Qiao, Pingli $\mathrm{He}$, Defa Li, Na Li, Xi Ma. Soybean Antigen Proteins and their Intestinal Sensitization Activities. Current Protein \& Peptide Science, volume 16, Issue 7,2015 , doi: 10.2174/1389203716666150630 134602 .

11. Drackley J.K. Calf nutrition related to heifer growth and longevity. 2000. P. 153-168.

12. Wattiaux M.A. Babcock Institutite for International Dairy Research and Development. University of Wisconsin. Bulletin: Heifer raisingweaning to calving 34, growth rate, 2000, pp. 133-136.

13. Lalles J.P., Toullec R., Branco Pardal P. and Sissons J.W. Hydrolyzed soy protein isolate sustains high nutritional performance in veal calves. J. Dairy Sci., 1995, 78, pp. 194-204.

\section{Сведения об авторах}

1. Асафов Владимир Александрович, кандидат технических наук, зав. сектором технологий функциональных продуктов и кормов, лаборатория ресурсосберегающих процессов и функциональных продуктов, ФГАНУ «Всероссийский научно-исследовательский институт молочной промышленности», 115093, Россия, г. Москва, ул. Люсиновская, 35, корп. 7, e-mail: v_asafov@ vnimi.org, ORCID: 0000-0001-8533-8649.

2. Харитонов Владимир Дмитриевич, доктор технических наук, главный научный сотрудник, академик РАН, лаборатория ресурсосберегающих процессов и функциональных продуктов, ФГАНУ «Всероссийский научно-исследовательский институт молочной промышленности», 115093, Россия, г. Москва, ул. Люсиновская, 35, корп. 7, e-mail: gnu-vnimi @ yandex.ru, ORCID: 0000-0002-1829-7360.

3. Танькова Нина Леонидовна, кандидат технических наук, старший научный сотрудник, сектор технологий функциональных продуктов и кормов, лаборатория ресурсосберегающих процессов и функциональных продуктов, ФГАНУ «Всероссийский научно-исследовательский институт молочной промышленности», 115093, Россия, г. Москва, ул. Люсиновская, 35, корп. 7, e-mail: n_tankova@vnimi. org.

4. Кузнецов Павел Владимирович, кандидат технических наук, ведущий научный сотрудник, лаборатория молочных консервов, ФГАНУ «Всероссийский научно-исследовательский институт молочной промышленности», 115093, Россия, г. Москва, ул. Люсиновская, 35, корп. 7, e-mail: p_kuznetsov@ vnimi.org.

5. Искакова Евгения Леонидовна, кандидат технических наук, ведущий научный сотрудник, сектор технологий функциональных продуктов и кормов, лаборатория ресурсосберегающих процессов и функциональных продуктов, ФГАНУ «Всероссийский научно-исследовательский институт молочной промышленности», 115093, Россия, г. Москва, ул. Люсиновская, 35, корп. 7, e-mail: e_iskakova@vnimi. org, ORCID: 0000-0002-9090-2678.

6. Габриелова Валентина Тихоновна, старший научный сотрудник, лаборатория молочных консервов, ФГАНУ «Всероссийский научно-исследовательский институт молочной промышленности», 115093, Россия, г. Москва, ул. Люсиновская, 35, корп. 7, e-mail: v_gabrielova@ vnimi.org. 
В данной статье приведены сведения о состоянии производства заменителей цельного молока для выпойки молодняка и дана характеристика способов и сырьевых источников их получения. Обсуждены некоторые аспекты развития технологий, направленные на получение качественных кормов при снижении энергозатрат на их производство. Одним из перспективных направлений повышения качества заменителей цельного молока является использование специализированных видов соевого белка, обладающих оптимизированным составом компонентов или подвергнутых определенной биотехнологической трансформации с целью расширения спектра функциональных свойств. Представлены сведения по влиянию скорости роста молодняка крупного рогатого скота на продуктивность молочного стада. Обозначены факторы, влияющие на развитие телят и продуктивность коров. Среди них - скорость роста телят, возраст и масса животного при первом отеле. Проведена зоотехническая оценка эффективности использования заменителей цельного молока на основе гидролизованного соевого белка, обезжиренных молока и соевой муки при выкармливании телят в возрасте от 4 до 84 дней. Результаты исследований указывают, что особое внимание следует обращать на выбор источника белка, используемого в заменителях молока. Показатели роста телят, вскармливаемых заменителями молока на основе гидролизованного соевого белка, были выше, чем при вскармливании другими кормами. Заданная масса достигалась при использовании заменителя молока на основе гидролизованного изолята соевого белка. За тот же период рост телят, вскармливаемых заменителем молока, содержащим соевую муку, был очень медленным и недостаточным для достижения заданного веса.

V. Asafov, V. Kharitonov, N. Tan'kova, Ye. Iskakova, P. Kuznetsov, V. Gabriyelova

\title{
SOME ASPECTS OF USING DIFFERENT SOY PROTEINS IN THE FEEDING DIETS OF CALVES
}

\author{
Key words: whole milk substitute; soy protein isolate; hydrolysis of proteins; soy flour; feeding factors; \\ calf growth.
}

\section{Authors' personal details}

1. Vladimir Asafov, Candidate of Technical Sciences, head of the sector of technologies of functional products and feed, laboratory of resource-saving processes and functional products, All-Russian Research Institute of the Dairy Industry, 115093, Russia, Moscow, Lyusinovskaya St., 35, building 7, e-mail: v_asafov@ vnimi.org, ORCID: 0000-0001-8533-8649.

2. Vladimir Kharitonov, Doctor of Technical Sciences, Chief Researcher, member of the Russian Academy of Sciences, Laboratory of resource-saving processes and functional products, All-Russian Research Institute of the Dairy Industry, 115093, Russia, Moscow, Lyusinovskaya St., 35, building 7, e-mail: gnu-vnimi@ yandex.ru, ORCID: 0000-0002-1829-7360.

3. Nina Tan'kova, Candidate of Technical Sciences, Senior Researcher, Sector of Technologies for Functional Products and Feed, Laboratory of Resource-Saving Processes and Functional Products, All-Russian Research Institute of the Dairy Industry, 115093, Russia, Moscow, Lyusinovskaya St., 35, building 7, e-mail: n_tankova@vnimi.org.

4. Pavel Kuznetsov, Candidate of Technical Sciences, Leading Researcher, Laboratory of Canned Dairy Products, All-Russian Scientific Research Institute of the Dairy Industry, 115093, Russia, Moscow, Lyusinovskaya St., 35, building 7, e-mail: p_kuznetsov@vnimi.org.

5. Evgeniya Iskakova, Candidate of Technical Sciences, Leading Researcher, Sector of Technologies for Functional Products and Feed, Laboratory of Resource-Saving Processes and Functional Products, All-Russian Research Institute of the Dairy Industry, 115093, Russia, Moscow, Lyusinovskaya St., 35, building 7, e-mail: e_iskakova@vnimi.org, ORCID: 0000-0002-9090-2678.

6. Valentina Gabrielova, Senior Researcher, Laboratory of Canned Dairy Products, All-Russian Research Institute of the Dairy Industry, 115093, Russia, Moscow, Lyusinovskaya St., 35, building 7, e-mail: v_gabrielova@vnimi.org. 
This article provides the production data of whole milk substitutes for feeding calves and describes the used techniques and raw materials. The study discusses some aspects of technology development to obtain high-quality feed while reducing energy costs. One of the promising directions for improving the quality of whole milk substitutes is soy protein specialized types with an optimized composition of components or subjected to a specific biotechnological transformation to expand the range of functional properties. Information is presented on the effect of the young cattle growth rate on the dairy herd's productivity. The factors influencing the development of calves and the productivity of cows are indicated. Among them are a calf growth rate, age, and weight of the animal at the first calving. A livestock-related efficiency assessment of the whole milk substitutes based on hydrolyzed soy protein, skim milk, and skimmed soy flour when feeding calves aged 4 to 84 days was carried out. Research results indicate that particular attention should be paid to selecting the protein source used in milk substitutes. Growth rates of calves fed milk substitutes based on hydrolyzed soy protein were higher than when fed other feeds. The target weight was achieved using a milk replacer based on hydrolyzed soy protein isolate. Over the same period, the growth of calves fed a milk replacer containing soy flour was very slow and insufficient to achieve a given weight.

(C) Асафов В.А., Харитонов В.Д., Танькова Н.Л., Искакова Е.Л., Кузнецов П.В., Габриелова В.Т.

УДК 619:616.1:636.5.084.087.8

DOI: $10.31563 / 1684-7628-2020-55-3-38-47$

И.Р. Долинин, Г.В. Базекин, Е.Н. Сковородин, И.В. Чудов, А.И. Лебедева

\section{МОРФОЛОГИЧЕСКАЯ ХАРАКТЕРИСТИКА ПЕЧЕНИ ЦЫПЛЯТ-БРОЙЛЕРОВ ПРИ ПРИМЕНЕНИИ НУКЛЕОСТИМА}

\section{Ключевые слова: Нуклеостим; биостимулятор; цыплята-бройлеры; печень; гистология; им- муногистохимия; CD 68; PCNA; casp 3.}

Введение. Значительная роль в обеспечении населения высококачественными продуктами питания принадлежит птицеводству. Интерес к этой отрасли постоянен как в крупных специализированных предприятиях, так и в малых фермерских хозяйствах, одновременно расширяется видовая гамма разводимой птицы от страусов до перепелов, хотя промышленное производство мяса и яиц кур более традиционно для сельского хозяйства. Кроме того, для этого налажены технологические мощности, созданы условия содержания и кормления птицы, преимуществом разведения сельскохозяйственной птицы являются также: малый расход кормов, короткий период воспроизводства, пластичность организма кур. Однако одного генетического потенциала организма птиц к производству продукции недостаточно - одним из ключей к экстенсивному наращиванию мощностей птицеводства является поиск возможностей применения биологически активных препаратов, обладающих биоактивными свойствами и оказывающих регулирующее влияние на рост и развитие птицы, интенсивность обменных процессов, способных уси- ливать функциональную активность органов и систем организма, повышать уровень естественной резистентности организма птиц, в то же время - безопасных для собственного организма, a её продукции - для человека и окружающей среды. На данный момент в различных источниках имеется информация о тканевых препаратах (биостимуляторах) и их благотворном влиянии на организм животных и птиц. Как правило, при их использовании происходит увеличение живой массы, улучшаются биохимические и физические показания крови и т. д. (даже без изменений условий содержания и кормления) $[1,8,9]$.

Цель исследований - изучить влияние биологического стимулятора Нуклеостим на гистологическую и гистохимическую картину печени цыплят-бройлеров 30-дневного возраста.

Материалы и методы. Экспериментальные животные. Для проведения исследований было использовано 40 цыплят-бройлеров кросса POCC 308. Опытные и контрольные группы животных содержались в одинаковых условиях на стандартном пищевом рационе со свободным доступом к воде [2, 3]. 